- Article type: paper

- Date: 9th June 2015

- Number of words in your main text and tables, followed by the number of figures.

\title{
A Systems Approach to Strategic Infrastructure Delivery
}

Author 1

- Michael Potts, Ba (hons), MA, BArch, ARB

- PhD Candidate, School of the Built Environment, University of Salford,

Author 2

- Peter McDermott, MSc, Phd

- Professor of Construction Management, School of the Built Environment, University of Salford

Author 3

- Andrew Stephenson, BSc (hons), MSc, MBA, FRICS, CIArb

- Industry Supervisor, UK WASC, Greater Manchester

Full contact details of corresponding author. 


\title{
Abstract (200 words)
}

This paper discusses a systems approach to the strategic delivery of infrastructure in the regulated UK water sector as part of a participatory focused research project. Part of an ongoing $\mathrm{PhD}$ programme, this paper highlights the value of a strategic approach to the procurement of infrastructure related services in accordance with the quinquennial water sector re-procurement exercise being undertaken by Infrastructure Client Organisations (ICO). As a strategic approach is concerned with understanding the delivery environment into which an organisation places, engages and delivers projects, this paper surfaces how a UK based Water and Wastewater ICO (UKWASC) has engaged with its delivery market, through procurement, to strategically position itself within the wider delivery environment to better serve its customers. Utilising a systems approach, what is brought to light here is the importance of organisational transitioning through change management, and how a delivery strategy can encompass the facilitation of organisational change.

\section{Keywords}

Infrastructure; Procurement; Project Management.

\author{
List of notation \\ UKWASC UK Based Water and Wastewater Infrastructure Client Organisation \\ ICO Infrastructure Client Organisation \\ ROI Return on Investment \\ PPP Public-Private Partnership \\ ICR Infrastructure Cost Review \\ TPCA Three Phase Change Approach \\ $P O \quad$ Participant Observation \\ $A R \quad$ Action Research \\ PAR Participatory Action Research \\ APT AMP6 Procurement Team \\ TMO Temporary Multi Organisation
}




\section{Introduction}

This paper presents the value of procurement in delivering lasting change within a UK based water and sewerage client organisation (UKWASC). Part of an ongoing PhD programme, this paper presents how a procurement exercise can represent a change vehicle within an Infrastructure Client Organisation (ICO), and how a participatory focused research project helped identify areas of emphasis for organisational change within the ICO. Utilising a systems approach to the strategic delivery of infrastructure, this paper sets out that an ICO has the capacity and capability to delivery infrastructure strategically to facilitate business and customer goals, but that identification of internal and market barriers to achieving efficient delivery practices need to be identified, espoused and addressed in order to facilitate lasting change.

\subsection{The Privatised Water Sector in England \& Wales}

Governments have sought to involve the private sector in the delivery of public services (Akintoye et al., 2003), and this involvement has been a focus in the delivery of infrastructure (Levy, 1996; Howes and Robinson, 2005), primarily concerned with providing the private sector with an appropriate return on investment (ROI) while ensuring the works are provided effectively and efficiently. The growth in the use of PPP's can be attributed to the process of government debt reduction; and the failure of traditional methods to deliver value-for-money service delivery (Watson, 2003). In the case of the delivery of critical assets, Akintoye and Renukappa (2013) suggest there are three forms of over-arching governmental approach to the delivery of infrastructure provision that exist, consisting of Pure Public Sector, Public-Private Partnerships (PPPs) and Pure Private Sector. In the case of the water industry in England and Wales, this is provided via a Pure Private Sector arrangement; resulting from the privatization of the industry in 1989 via divestiture or 'asset sales' (Finger and Allouche, 2002; Akintoye et al., 2003).

\subsection{The effectiveness of neo-liberalism}

Robison and Hewison (2005) stress the importance of the market, fiscal discipline, trade, investment and financial liberalisation, deregulation, decentralisation, privatisation and a reduced role for the state within neo-liberal reform strategies. Discussions continue within the body of literature around the effectiveness of privatization at achieving the intended neo-liberal reforms under which the industry was privatized (Van Den Berg, 1997; Rees, 1998; Saal and Parker, 2000; Finger and Allouche, 2002; Thomas and Ford, 2005; Prasad, 2006; Sawkins, 2012; Maziotis et al., 2012). While quality and customer satisfaction coupled with cumulative investment ( $£ 9.3$ billion in the six years before privatization and $£ 17$ billion during the six years following) is considered high compared with pre-privatization (Van Den Berg, 1997; Ofwat, 2011), efficiency levels are considered low while tariffs increased by $46 \%$ in the nine years following privatization, with operating profits more than doubling $(+142 \%)$ in eight years (Lobina and Hall, 2001). So with concerns around the wider effectiveness of the industry, ageing asset 
bases and forecast population growth (Akintoye and Renukappa, 2013), water sector ICOs must address these challenges in the face or more stringent regulatory pressure than ever

\subsection{Infrastructure Client Organisations}

ICOs within the UK have been under extensive pressure in recent times to economise their delivery processes, increase consistency and reliability within project delivery and maximise the outputs on return for investment. Authors such as Martin et al. (2006), EC Harris and TRL (2009), Flyvbjerg et al. (2008), HS2 (2009, 2012), NAO (2012), Cantarelli et al. (2010, 2012), Helm (2013) Madter and Bower (2015) and HM Treasury $(2010,2013)$ point toward increasing client and management costs, as well as a lack of skills and ability within ICOs. Indeed, the Infrastructure Cost Review (ICR) (HM Treasury, 2010) identified client leadership, overly complicated procurement practices and poor design specification as the top three areas for reducing costs.

Furthermore, the ICR (2010) identified a number of reasons for higher costs within funder and client organisations as being stop-start investment programmes; poor governance and ineffective incentivisation of cost control; poor asset information and cost data; specification, design and standard assets; commercial issues and procurement processes; and insurance. The ICR goes further to identify supply chain delivery issues as poor integration; low investment in innovation; low levels of skills and training; low productivity; and logistics. In the water sector, one can see reactions to such wider industry issues in the form of Infrastructure UK directed works such as 'Smoothing Investment Cycles in the Water Sector (HM Treasury, 2012), and from Ofwat (2013) in 'Setting price controls for 2015-2020 framework and approach' documentation. With stringent pressures from regulators and a drive towards a more open competition focused market in the water sector as soon as 2017 , it is important that water sector ICOs focus on reassessing their delivery arrangement today to provide a market leading service tomorrow.

\section{A Systems Approach to Delivery}

The reductionist method, focusing on items in isolation (and subsequently connected singularly), has been the predominant, almost dogmatist, problem solving methodology in western society to date (Leonard and Beer, 1994; Reynolds and Holwell, 2010). This cause and effect view of the world has been more than successful in providing many of the answers and descriptions of our natural world, but such thinking has struggled to see such fruitful returns in the social domain. A major issue is that the project environment, within which infrastructure delivery operates, is a complex and inherently temporary endeavour (Trist, 1963; Galbraith, 1973; Espejo, 1994; Packendorff, 1995; Hobday, 2000). Sargut and McGrath (2011) present that understanding complexity requires us to step away from complexity being used as a 
synonym for complicated, and that managing a complex organisation as if it were complicated can result in 'expensive mistakes'.

A heralded method of dealing with complex organisational scenarios has been the systems approach (Amagoh, 2008; Kast and Rosenzweig, 1972, 1974; Katz and Kahn, 1966; Checkland, 1981; Pasmore, 1988; Weiss 2007; Brown and Harvey, 2011). A key component of the systems approach is that it considers the bigger picture and the whole array of interdependencies and interrelationships that make up the greater organisational whole, especially through the identification (and modification) of emergent properties (Miller, 1967; Scott, 1987). Leonard and Beer (1994) present that the systems approach does not focus on 'parts' under the assumption that stitching them back together will result in the same outcome, but instead on 'wholes', in a highly contextually specific configuration and with more cyclical type causality relationships. As project complexity in the construction industry has been born of the wider fragmentation of the industry (Gidado, 1996; Wood and Ashton, 2010; Blayse and Manley, 2004; Mazet and Portier, 2010), the systems approach represents an appropriate lens through which to study the efficient project organisation.

\subsection{A Strategic Approach to Delivery}

It now becomes important to consider the operational components through which one economises. In procurement and delivery, this can be summated as taking a strategic approach, differentiating one from taking a tactical approach (Emmett and Crocker, 2008). Watermeyer (2012) considers that a strategic approach to infrastructure delivery spans the planning and management of the wider delivery process. According to Johnson and Scholes (1989), strategy is characteristically the direction of scope an organisation takes over the long term, achieving advantage through its configuration of resources within a changing environment to meet the needs of markets and stakeholder expectations. A strategic approach is thusly concerned with the maximisation of an organisation's market presence to leverage long term value from its supply chains. A strategic approach to construction procurement is in effect, the linkage between a businesses' strategic goals and the contingent operational reality that faces them (Cox and Townsend, 1998).

Mintzberg (1987) argues that decision makers are embedded in the decision making environment, not detached from it and thus strategies emerge from learning and compromise rather than grandstanding (Kochan et al., 1984). Strategic decision making is focused on long term implications for firms in terms of market structure, focusing on capacity and product characteristics for example, with tactical decisions representing more short term price or output foci (Church and Ware, 2000; Emmett and Crocker, 2008). Historically, delivery practices within the construction industry were concerned with singular transactions between buyers and sellers to suit the needs of specific projects (Arbulu and Tommelein, 2002). This led to the forming of boundary definitions between firms through specialisation (Dubois and Gadde, 2002); in turn 
leading to the wider fragmentation of the construction industry and its supply chains as a whole (Cox and Goodman, 1956; Blayse and Manley, 2004; Mazet and Portier, 2010). Previously, construction organisations sought to organise through the definition of internal boundaries based on functional specialism; this began to change as construction and engineering firms sought to integrate both internally and externally to economise and streamline processes and access to first tier suppliers. The modern result of this is the step beyond integration between a smaller number of firms and into the wider adoption of a Supply Chain Management (SCM) approach (Arbulu and Tommelein 2002). It is important to note however that Cox (1996) argues that the raison d'etre of the firm is to make profit (a margin), and that many researchers have focused on defining supply chain structures in terms of relationship (being the goal) rather than their fit for purpose nature in achieving the firms goals.

\section{Research Methodology}

Reinforced by Potts et al., (2014), the participatory approach deployed for this project is the Three Phase Change Approach (TPCA). This phased approach to both research and change builds on Lewin's Unfreeze, Move and Re-freeze (Lewin $\left.{ }_{2} 1951\right)$, whereby this project is aligned to a 3+ year relationship with the ICO. The main focus of this project is about engendering lasting change, and thus taking action. To do this, the TPCA breaks down into an initial 'Unfreeze' phase utilising Participant Observation (PO) (Marshall and Rossman, 1989; DeWalt and DeWalt, 2010; Bernard, 2011) which identifies the relevant organisational issues to be addressed. Following a process of engagement with the organisation, the project moves into the second phase (Move) which utilises a framework of Action Research (AR) (Shani and Pasmore, 1985; Coghlan and Brannick, 2005; McNiff and Whitehead, 2009) and begins to undertake a series of directed interventions within the ICO. This is followed by stage three (Re-freeze) which enacts a Participatory Action Research (PAR) approach (Whyte, 1991; Ottosson, 2003; Kindon et al., 2007), and whilst still focused on intervention, this phase utilises a more integrated research approach as the researcher's psychological contract develops within the focus ICO during the process (Rousseau, 1995; Rees and French, 2013).

What are presented in this paper are the results of the first PO phase and the structure of the procurement change process to which it aligns. PO serves as an important explanatory tool for a natural setting of study. PO is in essence a data collection method, whereby immersion of the researcher into the setting allows the researcher to gain a rich understanding of the factors affecting those being studied (DeWalt and DeWalt, 2010). By 'putting you where the action is' (Bernard, 2011), PO acts as one of several methods within the qualitative research framework, whereby the goal is to understand the nature of the phenomena opposed to quantification of it. Kutsche (1998) presents that in the analysis of observation field notes and interview information, the researcher is in essence attempting to make sense of and build descriptive models of what is happening. 


\subsection{Changing the Delivery Organisation}

Kast and Rosenzweig (1972) identify three levels of study when considering an organisation's effectiveness, namely its environment (within which it is located), the social organisation of the system itself and the people focused subsystems operating within the wider system structure. One prevalent issue here is the focus on 'effectiveness' and its linkage to an external vantage point, with 'efficiency' focusing on more controllable internal economic and technical activities (Katz and Kahn, 1966). It is therefore relevant to break down focus into the effectiveness of an organisation's external relationships in modification of its environment and the efficiency of its internal processes at achieving organisational goals. Improving organisational efficiency is a major rationale for the participation of the private sector in water supply, with the underlying idea that a drive toward profit making within a competitive market place will lead to operational streamlining (Ferdous Hoque and Gunawansa, 2013). The aim of initiatives such as privatisation focused on raising competitiveness through the use of techniques such as lean supply, partnership, network sourcing and outsourcing methods (Lamming and Cox, 1995; Cox et al., 1999); with the broad application of such approaches often considered as fads, rather than the appropriate use of tools to match any given environmental and situational specificities (Cox, 1996). Cox et al. (1999) argue that following privatisation, efficiency gains may depend upon the effectiveness of state regulation. With specific focus on monopoly supply, highly regulated state owned enterprise is considered the least satisfactory structure from an economic viewpoint, whilst changing the ownership to private, only intermediary improvements are achieved (Cox et al. 1996).

As a more entrepreneurial managerial approach is considered necessary for firms of all sizes to prosper in a competitive environment (Barringer and Bluedorn, 1999), the modification of organisational behaviour and attitudes becomes paramount when considering organisational efficiency. Daft (2012) identifies that organisations are social entities, goal oriented and designed (deliberately) in connection with their external environment. Consequently, Martin and Parker (1997) identify a variance of organisational characteristics between public and private organisations in terms of management, employment, internal architecture, nature and location of the business, mission and goals and internal communications. One key component would be the 'reactive' public management style versus 'pro-active' private sector management. As a strategic approach is concerned with leveraging long term value, it can be concluded that a proactive approach is a subservient requirement of one's strategic aims when considering procurement as a scientific discipline (Cox, 1996). Dobler and Burt (1996) assert that there is a transition underway from a transactional to a supply chain management approach, focusing on value-added benefits instead of internal process, and strategic management instead of tactical approaches. What this allows us to ascertain is that one must consider the pro-active strategic management of one's delivery organisation in order to achieve the intended efficiencies and reforms under which the industry was privatised. 
When considering a strategic approach, a key component is the focus on goals and goal setting. Martin and Parker (1997) present that market (private) oriented goals focus on commercial, consumer oriented, adaptable, market priced and output/outcome focused principles. To achieve such goals, one must consider that Mahoney and Weitzel (1969) give reference to the use of efficiency as a determinate criteria for the assessment of organisational effectiveness, and thus the efficient achievement of one's organisational goals can be said to be effective. With such high level goals defined by the focus ICO as a $65 \%$ reduction in project concept phases, $40 \%$ quicker overall delivery times, 20\% CAPEX reduction and a 0\% OPEX increase, the successful delivery of infrastructure is thusly concerned with managing organisational transitions toward achieving such goals in as an efficient manner as possible.

\section{Procurement exercise}

Lenard and Mohsini (1998) define procurement as a strategy that satisfies a client's needs through the provision of constructed facilities. While the value of such definitions has been questioned (McDermott, 1999), it is clear that a procurement strategy must address all aspects of a 'facility' to which a client has an interest (Walker and Rowlinson, 2008). Love et al. (1998) go further to define that a procurement system assigns the respective roles and responsibilities to both people and organisations as well as defining the multitude of project components, and thus can be perceived as an organisational system. What can be gleaned from these definitions is the formation of strategies based on appropriateness in response to contingent circumstances and client needs (Cox and Townsend, 1998). This is typically done through the application of tools and techniques ranging from spend analysis, relationship management, standard contract terms, collaborative strategies and a whole host of other methods. However one breaks it down, procurement is not merely about execution and adoption, but about organisational definition and understanding.

This then presents the opportunity to enact change through procurement to achieve organisational goals in a broader sense. As a systems view tells us that change in one part will ultimately be unsuccessful if not considerate of the wider picture in terms of holism, or at least the interactions of one's actions as part of a wider strategy, procurement must thus be seen as a vehicle for organisational change. Consequently, this section outlines the approach taken by the focus ICO in procuring its new delivery arrangements whilst also considering the wider impacts of such an exercise.

To begin, a simplified overview of the water sector delivery environment is presented by the authors (Figure 1), with readers directed toward the work of Thomas and Ford (2005) for a more in depth look into the UK water sector. What this outlines is the environmental situation facing the focus ICO in its procurement of the AMP6 relationships. As changes occur in one arena (such as legislation or service requirements to customers) a shift in emphasis is required within 
other areas (such as business structure or customer finance mechanisms) to respond to such environmental modifications.

\section{FIGURE 1}

As with the AMP6 procurement exercise, the focus ICO must respond to a multitude of environmental and organisational influences and change parameters in order to become effective. Congruently within the wider construction industry, the focus exercise is inherently complex from both a managerial and technological perspective (Gidado, 1996; Baccarini, 1996). As a way of dealing with such complexity, Cicmil and Hodgson (2006) identify that 'the project' (as a focal unit of organisational operation) is considered a suitable medium through which to control endeavours in a turbulent environment; whilst more importantly, projects also act as an appropriate way of stimulating learning environments and enhancing creativity in order to allow for the delivery of complex products. The resultant 'projectification of society' has focused on the rationalising of organisational activity with significant impact on issues such as workplace identity, inter-subjective interaction and increased control over individuals through efficiency and performance ideologies (Fournier and Grey, 2000).

The result of this identification of the AMP6 procurement exercise as complex opposed to complicated (Sargut and McGrath, 2011) is the formation of the AMP6 Procurement Team (APT) as a form of Temporary Multi Organisation, or TMO (Trist, 1963; Stringer, 1967; De Blois and Lizarralde, 2010; De Blois 2013). The APT becomes a formation of multiple actors from varying educational, operational, professional and departmental groups with differing aims and drivers coming together with a singular aim. The result is the establishment of an internal change team within UKWASC tasked with the creation and resultant successful procurement of UKWASC delivery strategies to fulfil the business needs. To provide the APT with the relevant resources and structure needed to deliver its task successfully, the following structure (Figure 2) was operationalised.

\section{FIGURE 2}

The APT was resourced by existing UKWASC functional areas, and then supported by additional resource streams from the market for areas such as market leading procurement skillset, additional legal support and assessment consultants etc. Additionally, this was also the main avenue through which this research project engaged with UKWASC. Governance was then arranged via a business (operational) steering group made up of senior leadership members to facilitate business wide processes and support, with a high level strategic board supporting decision making and providing direction to the programme of works. The APT flexed in response to changing demands of the over the 24+ month period, with the wider process broadly aligning to the following three phases. 


\subsection{Strategy}

This phase (see Figure 3 ) is concerned primarily with the identification of the business environment, issues and potential drivers. It includes wider market assessments in search of best practice and innovative approaches, but takes a strategic management approach in terms of forming a contingent strategy to suit business specificities. Engagement in this phase is across multiple delivery organisations, internal assessments, third party reviews and multi-level direction from business stakeholders. One could take from this exercise a need to continue, or start again; whatever the initial outcome, this is about understanding one's own organisation, market place, skillset, operational needs and wider business strategy / direction before departing on any course of action.

\section{FIGURE 3}

\subsection{Formation}

If a strategic decision is made to consider a step change, something entirely new or a modification to existing delivery practice, then the next phase is to work through the formation phase (see Figure 4). The aim here is to develop a finalised strategy having worked through a myriad of potential options and variations to best suit the business needs. As we look back to the higher level business needs during this phase, optioneering, core procurement component development and definition exercises can essentially be assessed as to whether they are achieving those goals. This wider strategy will unearth an array of organisational, managerial and technical issues to be addressed as part of a wider change management strategy with the procurement exercise finding the best fit between modification, renewal and removal strategies across the organisational delivery environment.

\section{FIGURE 4}

\subsection{Assess / Award / Mobilise}

Once a delivery strategy is formed, it is time to put it into practice with a focus on the assessment of, awarding to, and mobilisation of new delivery organisations (see Figure 5). An important component of a systemic procurement / change exercise is the drive to change the procuring organisation 'off the back' of the exercise. The procuring (client) organisation must not enter this phase 'with all the answers' or consider the supply market a subservient tool with which to 'do thy bidding' (as in more tactical relationships). The aim here is to undertake a robust procurement exercise, but also to reflect on one's own practice and eventual aims. Following extensive assessment phases such as worked examples and behavioural workshops, the procuring organisation needs to form change strategies that will help it respond and flex to the market within which it is operating. Such approaches allow one to step into the organisational mobilisation and resultant delivery phases (post award) with a view to changing 
existing organisational practices (predominantly underway) from the previous delivery arrangements so to better serve a systemic view of change.

\section{FIGURE 5}

\section{Focus on Change}

A strategic approach to a procurement exercise in effect sets the 'ball rolling' for wider organisational change. By this, it initially sets out by identifying the appropriateness of existing procurement relationships in (a) achieving the intended goals they were originally designed for and (b) their suitability to a modified organisational delivery environment. To coincide with the business change strategy, this project sought to identify, in accordance with the TPCA, a number of issues that could potentially be addressed through interventions as part of a wider strategic approach. In essence, identifying the organisational issues that would form the cornerstone of an effective research engagement. Beginning at the 'direction of travel' stage (within the strategy phase) and running through to the 'delivery strategy definition' stage (within the formation phase) the initial Participant Observation (PO) phase of the TPCA resulted in the definition (model creation) of a number of key organisational transition themes.

The subsequent themes are in no particular order:

\subsection{Delivery Alignment}

This represents an identified need to modify the existing ICO to reflect the revised delivery strategy; and the need to facilitate some of the required change processes early to realise an effective AMP6 delivery environment. Currently facilitating a series of alliance type delivery arrangement across a larger programme of works, the new delivery approach for AMP6 would require a step change in current delivery processes. To ensure the business experienced not only a smooth transition period but also a streamlined AMP6 delivery environment, many processes would need to get off the ground long before the start of AMP6 and potentially run congruently with the AMP5 delivery environment. This presents a large obstacle in terms of organisational transitioning and process streamlining, requiring respective change programmes to start in earnest before the appointment of new partners has begun. The consequence is the drive to align business delivery practices to the procurement vehicle in order to extract maximum value before its even started rolling.

\subsection{Adjudicative Resolution vs. Collaborative Feedback}

This discusses the use of 'representatives' as part of the APT (see Figure 6). By this, representatives act as fulcrums for knowledge on behalf of wider organisational (and external) sub-systems. Collaborative Feedback was partially observed and characterised as a desired way of dealing with the current systematic structure. In essence, this represents two key issues, 
the first being that of filtering, and the second being of implementing a systematic approach. In the Adjudicative Resolution model, the systematic process of knowledge 'handover' was practiced through the use of intermediaries, subject matter experts or representatives. This model did not create change at the rate demanded for the AMP6 programme due to authority, process and departmental knowledge issues. In the Collaborative Feedback model, better referred to as the desired system, change exists within (not to) a business unit and instead focuses on co-creation and co-education of value and knowledge. Here, change agents are colearners who step out of what can become a 'change silo' to work with business leads (and participants) to form a change strategy and work towards its integration into the 'whole'. This is about the 'change journey' opposed to the information handover.

\section{FIGURE 6}

\subsection{Systematic Delivery}

This has somewhat of a relationship with the above theme, but stands alone as an issue focused on practice and communication rather than change implementation. The issue here is primarily the maintenance of industry specialisation. The prevalent systematic approach is more akin to a reductionist, natural science approach, and as the AMP6 strategy sought to consider the delivery environment as a whole opposed to a series of streams with associated ownership structures, this would consequently require careful consideration. Here one begins to focus on the use of a systemic approach toward the delivery of infrastructure and revise some of the existing management and delivery structures accordingly. As within the wider construction industry, a general inclination of historical dogmatism toward traditional type procurement and delivery practices has led to internal organising that continues this practice opposed to a more strategic perspective. This might best be described as superordinate versus subordinate type goals. This misalignment can thus allow for the perpetuation of previous practice opposed to implementing change. It can be argued that bespoke specialism and knowledge ownership is by proxy the tenet of many construction industry professionals and that support of subordinate specialism in contrast (both communicatively and experientially) to the subordinate drivers of another is the appropriate manner in which to preserve ones inimitable skills. Whilst this may be an unavoidable truth, little is often done to align inherent specialism's to the broader strategic goals and thus no-one except those that know can possibly know how to know what one needs to know in order to dictate how one should experience what one knows......etc. Leading to a drive to step away from knowledge specialism into an environment of shared knowledge and joint problem solving of the whole, rather than the parts.

\subsection{Handover}

Opposed to joint design, specification and delivery as within alliance type environments, with multiple organisations taking projects from a particular delivery gateway through to fruition 
(considering the nature of the water sector in terms of setting initial Company Business Plans in isolation from delivery arrangements); in the revised AMP6 way of working, there would need to be a consideration of ownership, governance, singular authorities and contractual handover points etc. The AMP6 strategy is far more flexible delivery arrangement across multiple partners opposed to a singular delivery arrangement with organisational flexibility within it. It could be argued that both delivery vehicles contain flexibility, but in terms of changing the nature of the delivery environment, to continue the existing ways of working would not suit the new strategy in terms of efficiency internally, and efficacy externally. The key point is the move towards an optimised programme way of working, with elements of allocation and competition within and amongst the delivery chain to gain maximum value, rather than collective delivery. From a business change perspective, this means changing the mindset from one of delivery cycle ownership with an alliance type partner, to a stage gate type approach whereby different work types are released to the market at different times and managed accordingly depending on a variety of factors inclusive of value, work type and risk profile etc. The result is the requirement for a large step change amongst the delivery chain in terms of approach, skill sets and delivery methodology in order to match to the new ways of working.

\section{A Systems Approach to Action}

As part of this project, the preceding themes helped identify a number of interventions into the client organisation utilising a framework of participatory methods as part of the TPCA that helped engender lasting change. These interventions spanned the procurement activity across the assess / award / mobilise phase and then into the new delivery environment. The interventions focused on gaining maximum impact within the focus ICO in terms of the value the intervention could bring, inherent needs within the ICO, relevance to the theoretical underpinnings of the project and the ability of the intervention to address the themes defined by the PO phase. The resultant interventions included a behavioural assessment programme, delivery route allocation, client skills assessments, KPI creation, governance formation, contractual incentives mechanisms, programme optimisation and wider organisational and departmental re-design.

\section{Conclusion}

What this paper has aimed to highlight is the initial output from a three phased research approach to change within a UK based ICO. The focus of the project has been underpinned by a systems approach to the strategic delivery of infrastructure and the TPCA has been invaluable in achieving the main goal of effective change. The project identified a subset of change specifics that are not outlined here for a range of reasons including commercial sensitivity, but what the main themes do serve to identify is that (1) readiness for a revised delivery environment must start before actual delivery in order to 'smooth' out the transition between one delivery cycle and another; (2) that change must happen across organisational boundaries and 
as part of an assessment of organisational holism; (3) that the delivery chain is not automatically a systematic exercise delivered by individual knowledge owners, but can be looked at as more of a delivery whole with the same message and ideals being delivered across departmental boundaries; and (4) that a change in delivery approach requires that extensive consideration be given to the associated organisational delivery mechanisms in order to become efficient and effective. With mechanisms and literature in the industry beginning to focus on ICOs and the improvement of their delivery shill set (IUK, 2014; Bower, 2013), this project has helped identify a different way of thinking about change, but also, about how to implement it.

\section{Acknowledgements}

This project is being facilitated through the application of an Industrial Cooperative Award in Science \& Technology (iCase) PhD Studentship via the Engineering and Physical Sciences Research Council (EPSRC). The authors would like to UK WASC for not only their participation in this research, but their active role and the levels of access and cooperation provided.

For further detail please refer to the supplementary data section.

\section{References}

Akintoye, A., \& Renukappa, S. (2013). 4. The UK water industry: infrastructure, governance and. Water Governance: An Evaluation of Alternative Architectures, 81.

Akintoye, A., Beck, M., \& Hardcastle, C. (2003). Public-private partnerships. Blackwell Science.

Amagoh, F. (2008). Perspectives on organizational change: systems and complexity theories. The Innovation Journal: The public sector innovation journal, 13(3), 1-14.

Arbulu, R. J., \& Tommelein, I. D. (2002, August). Alternative supply-chain configurations for engineered or catalogued made-to-order components: case study on pipe supports used in power plants. In Proc. 10 th Annual Conference of the International Group for Lean Construction (pp. 6-8).

Baccarini, D. (1996). The concept of project complexity-a review. International Journal of Project Management, 14(4), 201-204.

Barringer, B. R., \& Bluedorn, A. C. (1999). The relationship between corporate entrepreneurship and strategic management. Strategic Management Journal, 20(5), 421-444.

Bernard, H. R. (2011). Research methods in anthropology. Rowman Altamira.

Blayse, A. M., \& Manley, K. (2004). Key influences on construction innovation. Construction innovation, 4(3), 143-154.

Bower, D. (2013, August). The new infrastructure procurement routemap: a global guide to improving delivery capability. In Proceedings of the ICE-Civil Engineering (Vol. 166, No. 3, pp. 99-99). Thomas Telford.

Brown, D. R., \& Harvey, D. (2011). An experiential approach to organization development. Upper Saddle River, NJ: Prentice Hall. 
Martin, J., Burrows, T., \& Pegg, I. (2006, October). Predicting construction duration of building projects. In XXIII Congreso FIG, Octubre de 2006.

Cantarelli, C. C., Flyvbjerg, B., Molin, E. J., \& Van Wee, B. (2010). Cost overruns in large-scale transportation infrastructure projects: explanations and their theoretical embeddedness. European Journal of Transport Infrastructure Research, 10(1), 5-18.

Cantarelli, C. C., Molin, E. J., Van Wee, B., \& Flyvbjerg, B. (2012). Characteristics of cost overruns for Dutch transport infrastructure projects and the importance of the decision to build and project phases. Transport Policy, 22, 49-56.

Checkland, P. (1981). Systems thinking, systems practice.

Church, J. R., \& Ware, R. (2000). Industrial organization: A strategic approach.

Cicmil, S., \& Hodgson, D. (2006). New possibilities for project management theory: A critical engagement. Project Management Journal, 37(3), 111.

Coghlan, D., \& Brannick, T. (2005).Doing Action Research in Your Own Organisation.2nd ed, London, Sage.

Cox, R., \& Goodman, C. S. (1956). Marketing of house building materials. The Journal of Marketing, 36-61.

Cox, A., \& Townsend, M. (1998). Strategic procurement in construction. Thomas Telford Limited.

Cox, A., Harris, L., \& Parker, D. (1996). Confusion and Uncertainty in Procurement Management: The impact of privatisation on buyer and supplier relationships. Occasional paper in industrial strategy, Brimingham Business School, No. 38, June, ISBN 0-7044-1719

Cox, A., Harris, L., \& Parker, D. (1999). Privatisation and Supply Chain Management.

Cox, A. (1996). Relational competence and strategic procurement management: Towards an entrepreneurial and contractual theory of the firm. European Journal of Purchasing \& Supply Management, 2(1), 57-70.

Daft, R. (2012). Organization theory and design. Cengage learning.

de Blois, M (2013): The "self-organizing" project": a "systemic" view of the design and project rocesses. Relating Systems Thinking and Design 2013 Working paper.

de Blois, M. \& Lizarralde, G. (2010). A System of Classification of Temporary MultiOrganizations in the Building Sector. Paper presented at the CIB World Building Congress 2010, Salford.

DeWalt, K. M., \& DeWalt, B. R. (2010).Participant observation: A guide for fieldworkers. Rowman Altamira.

Dobler, D.W, Burt, D.N. (1996); Purchasing and Supply Management, 6th edition, New York et al. 1996.

Dubois, A., \& Gadde, L. E. (2002). The construction industry as a loosely coupled system: implications for productivity and innovation. Construction Management \& Economics, 20(7), 621-631. 
EC Harris and Transport Research Laboratory (2009); Project Report CPR596, European Cost Comparison - Cost Differences between English and Dutch Highway Construction. EC Harris and TRL

Emmett, S., \& Crocker, B. (2008). Excellence in Procurement: How to optimise costs and add value. Cambridge academic.

Espejo, R. (1994). What is systemic thinking?. System Dynamics Review, 10(2), 199-212.

Finger, M., \& Allouche, J. (2002). Water privatisation. Transnational Corporations and the ReRegulation of the Water Industry, Spon Press, London, New York.

Flyvbjerg, B., Bruzelius, N., \& Van Wee, B. (2008). Comparison of capital costs per routekilometre in urban rail. European journal of transport and infrastructure research, 8(1), 17-30.

Fournier, V., \& Grey, C. (2000). At the critical moment: Conditions and prospects for critical management studies. Human relations, 53(1), 7-32.

Galbraith, J. R. (1973). Designing complex organizations. Addison-Wesley Longman Publishing Co., Inc..

Gidado, K. I. (1996). Project complexity: The focal point of construction production planning. Construction Management \& Economics, 14(3), 213-225.

Helm, D. (2013). British infrastructure policy and the gradual return of the state. Oxford Review of Economic Policy, 29(2), 287-306.

Treasury, H. M., \& UK, I. (2010). Infrastructure Cost Review: Technical Report. HM Treasure and Infrastructure UK, London, UK.

Infrastructure UK (2012). Smoothing investment cycles in the water sector. HM Treasury, UK

Infrastructure UK (2013). Infrastructure procurement route map: a guide to improving delivery capability. HM Treasury, UK

Madter, N., \& Bower, D. (2015). Briefing: The Institution of Civil Engineers' intelligent client capability framework. Proceedings of the ICE-Management, Procurement and Law, 168(1), 6-7.

Hobday, M. (2000). The project-based organisation: an ideal form for managing complex products and systems?. Research policy, 29(7), 871-893.

Ferdous Hoque, S., \& Gunawansa, A. (2013). Good governance of water: The final analysis.

Howes, R., \& Robinson, H. (2005). Infrastructure for the built environment: Global procurement strategies. Routledge.

HS2 Ltd (2009), High Speed Rail London to the West Midlands and Beyond: HS2 Cost and Risk Model

HS2 Ltd (2012), HS2 Cost and Risk Model Report, A report to Government by HS2

Johnson, G. \& Scholes, K., Exploring Corporate Strategy: Text and Cases (London: PrenticeHall, 1989).

Kast, F. E., \& Rosenzweig, J. E. (1974). Organization and management: A systems approach. McGraw-Hill.

Kast, F. E., \& Rosenzweig, J. E. (1972). General systems theory: Applications for organization and management. Academy of management journal, 15(4), 447-465. 
Katz, D., \& Kahn, R.L. (1966). The social psychology of organizations. New York: Wiley,1966

Kindon, S., Pain, R., \& Kesby, M. (Eds.). (2007). Participatory action research approaches and methods: Connecting people, participation and place. Routledge.

Kochan, T. A., McKersie, R. B., \& Cappelli, P. (1984). Strategic choice and industrial relations theory. Industrial Relations: A Journal of Economy and Society, 23(1), 16-39.

Kutsche, Paul (1998). Field ethnography: A manual for doing cultural anthropology. Upper Saddle River, NJ: Prentice Hall.

Lamming, R., \& Cox, A. (Eds.). (1995). Strategic procurement management in the 1990s: Concepts and cases. Earlsgate.

Lenard, D. and Mohsini, R. (1998). Recommendations from the Organisational Workshop. CIB W-92 Procurement - The Way Forward. The University of Montreal, 18-22 May, Davidson C. H. and T. A. Meguid, CIB, 1: 79-81.

Leonard, A., \& Beer, S. (1994). The systems perspective: Methods and models for the future. AC/UNU Project.

Levy, S. M. (1996). Build, operate, transfer: paving the way for tomorrow's infrastructure. John Wiley \& Sons.

Lewin, K. (1951). Field theory in social science: selected theoretical papers (Edited by Dorwin Cartwright.).

Lobina, E., \& Hall, D. (2001). UK water privatisation: a briefing. London: Public Services International Research Unit.

Love, P. E., Skitmore, M., \& Earl, G. (1998). Selecting a suitable procurement method for a building project. Construction Management \& Economics, 16(2), 221-233.

Mahoney, T. A., \& Weitzel, W. (1969). Managerial models of organizational effectiveness. Administrative Science Quarterly, 357-365.

Marshall, C., \& Rossman, G. B. (1989). Design qualitative research. Calfornia: Sage.

Martin, S., \& Parker, D. (2003). The Impact of Privatization: Ownership and Corporate Performance in the United Kingdom. Routledge.

Crespin-Mazet, F., \& Portier, P. (2010). The reluctance of construction purchasers towards project partnering. Journal of Purchasing and Supply Management, 16(4), 230-238.

Maziotis, A., Saal, D. S., \& Thanassoulis, E. (2012). Profit, productivity and price performance changes in the English and Welsh Water and Sewerage companies (No. 84.2012). Nota di Lavoro, Fondazione Eni Enrico Mattei.

McDermott, P. (1999). Strategic and emergent issues in construction procurement. Procurement systems: A guide to best practice in construction.

McNiff, J., \& Whitehead, J. (2009).You and your action research project. Routledge.

Miller, E (1967). Systems of Organisation. London, Tavistock: 1967

Mintzberg, H. (1987). Crafting strategy (pp. 66-75). Boston, MA: Harvard Business School Press.

NAO (2012). The completion and sale of High Speed 1; National Audit Office, UK 
Ofwat (2013). Setting price controls for 2015-20 - framework and approach: A consultation (The Water Services Regulation Authority)

OFWAT (2011). Service and delivery - performance of the water companies in England and Wales 2009-10

Ottosson, S. (2003). Participation action research-: A key to improved knowledge of management. Technovation, 23(2), 87-94.

Packendorff, J. (1995). Inquiring into the temporary organization: new directions for project management research. Scandinavian journal of management, 11(4), 319-333.

Pasmore, W. A. (1988). Designing effective organizations: The sociotechnical systems perspective (Vol. 6). John Wiley \& Sons Inc.

Potts, M, Awuzie, B, McDermott, P and Stephenson, A (2014), 'Engendering Change within a Water Infrastructure Client Organisation: A Participatory Action Research Approach', proceedings from the $5^{\text {th }}$ International Conference on Engineering, Project and Production Management, Port Elizabeth, South Africa, 26-28 November 2014.

Prasad, N. (2006). Privatisation results: private sector participation in water services after 15 years. Development Policy Review, 24(6), 669-692.

Rees, G., \& French, R. (2013). Leading, managing and developing people (No. 4th). CIPD Publications Rees, J. A. (1998, May). Regulation and private participation in the water and sanitation sector. In Natural Resources Forum (Vol. 22, No. 2, pp. 95-105). Blackwell Publishing Ltd.

Reynolds, M., \& Holwell, S. (2010). Introducing systems approaches. In Systems Approaches to Managing Change: A Practical Guide (pp. 1-23). Springer London.

Rousseau, D. (1995). Psychological contracts in organizations: Understanding written and unwritten agreements. Sage Publications.

Saal, D. S., \& Parker, D. (2000). The impact of privatization and regulation on the water and sewerage industry in England and Wales: a translog cost function model. Managerial and Decision Economics, 21(6), 253-268.

Sargut, G., \& McGrath, R. G. (2011). Learning to live with complexity. Harvard Business Review, 89(9), 68-76.

Sawkins, J. W. (2012). The introduction of competition into the Scottish Water industry. Utilities Policy, 20(1), 22-30.

Scott, Richard W. (1987): "Organizations: Rational, Natural and Open Systems," Englewood Cliffs, , Prentice-Hall

Shani, A. B., \& Pasmore, W. A. (1985). Organization inquiry: Towards a new model of the action research process. Contemporary Organization development: Current Thinking and Applications, Scott, Foresman, Glenview, IL, 438-448.

Stringer, J. (1967). Operational research for" multi-organizations". OR, 105-120.

Thomas, D. A., \& Ford, R. R. (2005). The crisis of innovation in water and wastewater. Edward Elgar Publishing. 
Trist, E. L. (1963) Organizational choice: capabilities of groups at the coal face under changing technologies: The loss, re-discovery. London: Tavistock

Van den Berg, C. (1997). Water privatization and regulation in England and Wales.

Walker, D., \& Rowlinson, S. (2008). Procurement systems: a cross-industry project management perspective. Routledge.

Watermeyer, R. B. (2012). A framework for developing construction procurement strategy. Proceedings of the ICE-Management, Procurement and Law, 165(4), 223-237.

Watson, D. (2003). The rise and rise of public private partnerships: challenges for public accountability. Australian Accounting Review, 13(31), 2-14.

Weiß, M. (2007):Efficient Organizational Design - Balancing Incentives and Power. Palgrave Macmillan, Basingstoke.

Whyte, W. F. E. (1991). Participatory action research. Sage Publications, Inc.

Wood, H., \& Ashton, P. (2010). Modelling project complexity.

Figure captions (images as individual files separate to your MS Word text file).

Figure 1. ICO Delivery Environment

Figure 2. AMP6 TMO

Figure 3. Procurement Strategy Phase

Figure 4. Procurement Formation Phase

Figure 5. Procurement Assess / Award / Mobilise Phase

Figure 6. Adjudicative Resolution vs. Collaborative Feedback 